\title{
STUDI DESKRIPTIF PERILAKU ANAK USIA 9-12 TAHUN TENTANG PENCEGAHAN PENULARAN COVID-19 DI MADRASAH DINIYAH AWALIYAH MA'ARIF NU 01 AL-HIDAYAH DEMAAN JEPARA
}

\author{
Descriptive Study of Behavior of Children Aged 9-12 Years About The \\ Prevention of The Transmission of COVID-19 in The Madrasah Diniyah \\ Awaliyah Ma'arif Nu 01 Al-Hidayah Demaan Jepara
}

\author{
Devi Rosita ${ }^{1}$, Nofa Krisdiana ${ }^{2}$ \\ ${ }^{1}$ Universitas Al Hikmah Jepara, Indonesia \\ ${ }^{2}$ Universitas Al Hikmah Jepara, Indonesia
}

Korespondensi: Devi Rosita dan devirosita2508@gmail.com

\begin{abstract}
ABSTRAK
Latar Belakang: Wabah COVID-19 ditetapkan sebagai pandemi global. Angka COVID-19 di Jepara pada anak usia 9-12 tahun 107 kasus terkonfirmasi. Sistem imunitas pada anak belum sempurna dapat membuat anak lebih rentan terinfeksi virus corona Mulai bulan juli 2020 sudah diberlakukan kegiatan pembelajaran oleh ketua Madrasah Diniyah Awaliyah Ma'arif Nu 01 AL-Hidayah Demaan Jepara. Tujuan: Penulisan ini untuk mengetahui gambaran perilaku anak usia 912 tahun tentang pencegahan penularan COVID-19 di Madin Awaliyah AlHidayah Demaan Jepara. Metode: Jenis penulisan deskriptif, populasi penulisan adalah seluruh siswa Madin Awaliyah Ma'arif Nu 01 Al- Hidayah Demaan Jepara yang berusia 9-12 th. Sampel 49 responden, Tehnik sampling menggunakan total sampling dan instrumen yang digunakan ceklis dan kuesioner. Analisa data menggunakan univariat dengan menggunakan distribusi frekuensi. Hasil: Sebagian besar anak usia 9-12 tahun di Madin Al- Hidayah tidak melakukan perilaku pencegahan penularan COVID-19. Mencuci tangan dengan baik 44 orang $(89,8 \%)$ tidak mencuci tangan dengan baik dan benar 5 orang $(10,2 \%)$. Tidak memakai masker 31 orang $(63,3 \%)$ memakai masker 18 orang $(36,7 \%)$, tidak jaga jarak fisik 31 orang (63,3\% )jaga jarak fisik (36,7\%). Kesimpulan: Ada hubungan antara pengetahuan dan motivasi ibu mengkonsumsi tablet besi di PMB Luh Putu Yuniasih, S.ST, hal ini menunjukkan pengetahuan merupakan penentu adanya motivasi pada ibu hamil dalam mengkonsumsi tablet besi.
\end{abstract}

Kata Kunci: Perilaku; Anak; Pencegahan; COVID-19.

\section{ABSTRACT}

Background: The COVID-19 outbreak is designated as a global pandemic. The number of COVID-19 in Jepara in children aged 9-12 years 107 confirmed cases of immune system in children is not perfect can make children more susceptible to infection with the virus. In July 2020, there have been different learning activities by the head of Madrasah Diniyah. Awaliyah Ma'anf Nu01 AL-Hidayah Demaan Jepara. Objective: of this study is to find out an overview of the behavior of children aged 9-12 years about the prevention of COVID-19 transmission in Madin Awaliyah Al-Hidayah Demaan Jepara. Methods: Descriptive type 
Devi Rosita \& Nofa Krisdiana: Studi Deskriptif Perilaku Anak Usia 9-12 Tahun tentang Pencegahan Penularan COVID-19 di Madrasah Diniyah Awaliyah Ma'arif Nu 01 Al-Hidayah Demaan Jepara

research. The study population was the entire student of Madin Awaliyah Ma'arif $\mathrm{Nu} 01$ Al-Hidayah Demaan Jepara who was 912 years old. A sample of 49 respondents. Sampling techniques use total sampling and. Instruments used in questionnaires and questionnaires. Results: Most of children aged 9-12 years in Madin Al-Hidayah did not conduct preventive behavior of COVID-19 transmission. Good hand washing 44 people (89.8\%) did not wash their hands properly and correctly 5 people (10.2\%). Not wearing a mask 31 people (63.3\%) wear masks 18 people (36.7\%). Do not maintain physical distance 31 people (63.3\%) physical distance (36.7\%). Conclusion: The research place is expected to support children'sbehavior as a prevention of COVID- 19 transmission so that it does not spread widely by favoring refleats and pamphlets containing health protocols, conducting limited face to face learning, giving directions for children to always comply with health protocols, always providing masks, hand washing places, soap and hand sanitizers.

Keywords: Behavior; Children; Prevention; COVID-19.

\section{PENDAHULUAN}

Saat ini dunia dikejutkan dengan wabah suatu penyakit yang disebabkan oleh sebuah virus yang bernama corona atau nama lainnya COVID-19. Coronavirus Disease 2019 (COVID-19) adalah penyakit jenis baru yang belum pernah diidentifikasi sebelumnya pada manusia. Virus penyebab COVID-19 ini dinamakan Sars-CoV-2. Virus corona adalah zoonosis yang ditularkan antara hewan dan manusia. Penelitian menyebutkan bahwa SARS ditransmisikan dari kucing luwak atau civet cats ke manusia dan MERS dari unta ke manusia. Adapun hewan yang menjadi sumber penularan COVID 19 ini masih belum diketahui. (Kemenkes, 2020).

Di Indonesia situasi kasus COVID-19 pada anak tanggal 17 oktober 2020 yang sedang dalam perawatan pada usia 0 tahun sebanyak 6\%, 1-4 tahun $14 \%, 5-6$ tahun $6 \%, 7-12$ tahun $26 \%, 13-15$ tahun $21 \%, 16-18$ tahun $27 \%$. kasus meninggal pada anak 0 tahun sebanyak 29\%, 1-4 tahun 15\%, 5-6 tahun $4 \%, 7-12$ tahun $18 \%, 13-15$ tahun $10 \%, 16-18$ tahun $24 \%$. Kasus sembuh pada anak 0 tahun sebanyak $6 \%, 1-4$ tahun $14 \%, 5-6$ tahun 7\%, 7-12 $27 \%$, 13- $1520 \%$, 16-18 $25 \%$. ( Kemenkes RI 2020 )

Di Indonesia angka kematian anak berdasarkan usia akibat COVID-19 pada anak usia 0-5 tahun sebanyak 2,7 \% (573) , pada anak usia 6- 18 tahun sebanyak 8,8\% ( 1.868) dari 21.237 jumlah kasus kematian akibat COVID-19 per 27 desember 2020 (data satgas COVID19 2020).

Jepara melaporkan pada 8 Desember 2020 terdapat 2.984 total positif kasus di Jepara, terkonfirmasi saat ini 617 positif, 2.170 terkonfirmasi suspek, terkonfirmasi sembuh 2.150 dan terkonfirmasi meninggal 217. (Satuan Tugas Penanganan COVID-19 Kabupaten Jepara).

Sampai tanggal 26 januari 2021 kejadian COVID-19 pada anak usia 9 - 12 tahun di kabupaten jepara sebanyak 107 kasus terkonfirmasi, terkonfirmasi di rujuk 1, terkonfirmasi di isolasi 62, terkonfirmasi sembuh 44. Berdasarkan data dari dinas 
kesehatan kabupaten jepara kasus COVID-19 pada anak usia 9-12 tahun terbanyak berada di kecamatan Jepara dan terendah di Donorojo dan Kalinyamat.

Anak adalah seseorang yang belum beruasia 18 tahun, termasuk anak yang masih dalam kandungan (UU RI No.23 th 2002 tentang perlindungan anak). Sistem imunitas pada anak belum sempurna dapat membuat anak lebih rentan terinfeksi virus corona. Selain itu sifat anak yang selalu ingin tau dan masih susah untuk di atur atau diberi nasihat maka orang tua perlu memberi pengetahuan dan penjelasan mengenai virus corona pada anak secara jelas dan berulang kali supaya anak lebih faham mengapa mereka harus menjaga kesehatan selama masa pandemik virus corona Darmawan, 2020).

Berdasarkan studi pendahuluan yang dilakukan oleh penulis pada tanggal 21 Januari 2021 sampai dengan 26 Januari 2021 ditemukan kasus COVID- 19 anak usia 9-12 tahun terbanyak di Jepara berada di kecamatan Jepara desa Demaan dan hasil survei jumlah siswa madin terbanyak di desa Demaan yaitu Madin Al Hidayah dengan jumlah siswa 170 dengan metode pertemuan kelas.

\section{TUJUAN PENELITIAN}

Penulisan ini untuk mengetahui gambaran perilaku anak usia 9-12 tahun tentang pencegahan penularan COVID-19 di Madin Awaliyah AlHidayah Demaan Jepara.

\section{METODE PENELITIAN}

Penelitian ini merupakan
penelitian jenis deskriptif.
Variabelnya adalah perilaku anak
usia $9-12$ tahun terhadap

pencegahan penularan COVID-19. Sub variabelnya adalah mencuci tangan, memakai masker dan jaga jarak fisik. Populasi dalam penelitian ini adalah seluruh siswa Madin Awaliyah Al-Hidayah yang berusia 9- 12 tahun sebanyak 49 siswa. Tehnik sampling yang digunakan adalah total sampling. Data yang dikumpulkan adalah data primer dan data sekunder. Data primer diperoleh dari pengumpulan data yang dilakukan oleh peneliti dengan lembar ceklis dan kuesioner, dan data sekunder diperoleh dari $\mathrm{Tu}$ Madin jumlah siswa Madin dan yang berusia 9-12 tahun .penelitian ini menggunakan alat pengumpul ceklis dan kuesioner. Penelitian ini menggunakan analisa Univariat dengan distribusi frekuensi.

\section{HASIL PENELITIAN}

Tabel 1. Distribusi Frekuensi

Berdasarkan Perilaku Mencuci

Tangan Anak Usia 9-12 tahun tentang pencegahan penularan

COVID-19

\begin{tabular}{lcr}
\hline $\begin{array}{l}\text { Perilaku } \\
\text { Mencuci } \\
\text { Tangan }\end{array}$ & Frekuensi & Persentase \\
\hline Baik & 44 & $89,8 \%$ \\
Tidak & 5 & $10,2 \%$ \\
Baik & & $100 \%$ \\
\hline Total & 49 & \\
\hline
\end{tabular}

Berdasarkan hasil penelitian melalui pengamatan dan ceklis cuci tangan yang baik dengan sabun menurut WHO dari jumlah 49 responden, didapatkan hasil responden yang melakukan cuci tangan dengan baik dan benar 44 orang ( $89,8 \%$ ) lebih besar dari pada tidak mencuci tangan dengan baik dan benar yaitu $5(10,2 \%)$. 
Devi Rosita \& Nofa Krisdiana: Studi Deskriptif Perilaku Anak Usia 9-12 Tahun tentang Pencegahan Penularan COVID-19 di Madrasah Diniyah Awaliyah Ma'arif Nu 01 Al-Hidayah Demaan Jepara

Tabel 2. Distribusi frekuensi berdasarkan Perilaku Memakai Masker Anak Usia 9-12 Tahun tentang Pencegahan Pencegahan Penularan COVID-19

\begin{tabular}{lcr}
\hline $\begin{array}{l}\text { Perilaku } \\
\text { Memakai } \\
\text { masker }\end{array}$ & Frekuensi & Persentase \\
\hline Memakai & 18 & 36,7 \\
Tidak & 31 & 63,3 \\
Memakai & & \\
\hline Total & 49 & $100 \%$ \\
\hline
\end{tabular}

Berdasarkan hasil penelitian melalui pengamatan pertanyaan dan lembar observasi dari jumlah 49 responden, didapatkan hasil responden yang tidak memakai masker yaitu 31 orang $(63,3 \%)$ lebih besar dari pada yang memakai masker yaitu 18 orang $(36,7 \%)$.

Tabel 3. Distribusi Frekuensi Berdasarkan Perilaku Jaga Jarak Fisik Anak Usia 9-12 Tahun Tentang Pencegahan Penularan COVID-19

\begin{tabular}{lcr}
\hline $\begin{array}{l}\text { Perilaku } \\
\text { physical } \\
\text { distancing } \\
\text { (jaga jarak }\end{array}$ & Frekuensi & Persentase \\
fisik) & & \\
\hline Jaga Jarak & 18 & 36,7 \\
$\begin{array}{l}\text { Tidak Jaga } \\
\text { jarak }\end{array}$ & 31 & 63,3 \\
\hline Total & 49 & $100 \%$ \\
\hline
\end{tabular}

Berdasarkan hasil penelitian melalui pengamatan dan ceklis dari jumlah 49 responden didapatkan hasil responden yang tidak melakukan jaga jarak fisik yaitu 31 orang $(63,3 \%)$ lebih besar dari pada yang melakukan jaga jarak fisik yaitu 18 orang $(36,7 \%)$.

\section{PEMBAHASAN}

Sebagian besar anak- anak melakukan cuci tangan dengan baik dan benar, mereka mendapatkan informasi mengenai cuci tangan yang baik dan benar dari media sosial dan mendapat pendidikan kesehatan dari guru sekolah pagi kemudian mempraktikan sebelum masuk kelas dan sering mencoba dirumah, dan berdasarkan hasil wawancara peneliti dengan ustadzah diperoleh keterangan bahwa tidak ada petugas kesehatan yang datang untuk memberikan pendidikan kesehatan di Madin Awaliyah Al- HIdayah. Selain itu Madin menyediakan tempat cuci tangan dan menyediakan sabun untuk mencuci tangan dan hand sanitizer di setiap kelas, ustadz dan ustadzah selalu mengingatkan untuk mencuci tangan sebelum dan sesudah masuk kelas.

Banyak anak yang tidak memakai masker karena menurut anak- anak tidak nyaman jika selama pembelajaran memakai masker, merasa engap untuk bernafas, berdasarkan hasil wawancara peneliti dengan ustadzah diperoleh keterangan bahwa tidak ada petugas kesehatan yang datang untuk memberikan pendidikan kesehatan sebagai pencegahan penularan COVID-19 khususnya memakasi masker di Madin Awaliyah AlHIdayah namun Madin sudah mendapat bantuan masker dari partai partai dan dari Kementrian Agama. Sebenarnya anak- anak membawa masker setelah masuk kelas masker di taruh di dalam tas atau di saku di kantong.

Anak-anak Memakai masker tidak sesuai dengan prosedur dari Kemenkes RI, anak-anak sering membuka pasang masker, memakai masker tidak menutupi bagian 
Devi Rosita \& Nofa Krisdiana: Studi Deskriptif Perilaku Anak Usia 9-12 Tahun tentang Pencegahan Penularan COVID-19 di Madrasah Diniyah Awaliyah Ma'arif Nu 01 Al-Hidayah Demaan Jepara

hidung mulut dagu, sering menyentuh masker bagian depan. Ustadz utadzah sering mengingatkan untuk selalu memakai masker.

Sebagian besar anak tidak melakukan jaga jarak fisik atau physical distancing karena anakanak tidak bisa jauh dari teman teman selain itu berdasarkan hasil wawancara peneliti dengan ustadzah diperoleh keterangan bahwa tidak ada petugas kesehatan yang datang untuk memberikan pendidikan kesehatan sebagai pencegahan penularan COVID-19 khususnya menjaga jarak fisik di Madin Awaliyah Al- HIdayah.

Masih rendahnya pelaksanaan pencegahan penularan COVID-19 khususnya menjaga jarak fisik anak usia 9-12 tahun di Madin Awaliyah Al- Hidayah disebabkan masih kurangnya informasi dan pengetahuan anak tersebut tentang menjaga jarak fisik, kurangnya fasilitas sarana yang mendukung kegiatan pencegahan penularan COVID-19 di Madin untuk melakukan jaga jarak fisik Madin tidak menjarak kan meja dan tempat duduk karena ruangan kelas yang kurang luas jika di lakukan penjarak kan meja dan tempat duduk maka ruangan tidak cukup. Ustadz dan Ustadzah pun melarang anak untuk kontak fisik bersalaman saat pulang.

\section{KESIMPULAN}

Berdasarkan hasil penelitian yang telah dilakukan dengan judul study deskriptif perilaku anak usia 912 tahun tentang pencegahan penularan COVID-19 di Madrasah Diniyah Awaliah Al Hidayah Demaan Jepara dapat ditarik kesimpulan sebagai berikut:

1. Anak usia 9-12 tahun di Madrasah Diniyah Al- Hidayah sebagian besar melakukan perilaku mencuci tangan dengan baik dan benar yaitu sebanyak 44 orang $(89,8 \%) \quad$ sedangkan sebagian kecil tidak melakukan perilaku mencuci tangan dengan baik dan benar yaitu 5 orang $(10,2 \%)$.

2. Anak usia 9-12 tahun di Madrasah Diniyah Al- Hidayah sebagian besar tidak memakai masker yaitu sebanyak 31 orang $(63,3 \%)$ sedangkan yang memakai masker sebanyak 18 orang $(36,7 \%)$.

3. Anak usia 9-12 tahun di Madrasah Diniyah Al- Hidayah sebagian besar tidak melakukan jaga jarak fisik sebanyak yaitu sebanyak 31 orang $(63,3 \%)$ sedangkan sebagian kecil melakukan jaga jarak fisik yaitu sebanyak 18 orang $(36,7 \%)$.

\section{DAFTAR PUSTAKA}

Adinda,Dhea.Rasmithadila. (2021).

Penyuluhan Kebersihan

Melalui Program Cuci

Tangan Sebagai Bentuk

Kesadaran AnakAnak Di

Masa Pandem Covid-19.

Atmojo, Jokotri.iswahyuni. rejo dkk.

(2020). Penggunaan Masker

Dalam Pencegahan Dan

Penanganan Covid-19

Rasionalitas,Efektifitas Dan Isu terkini.

Dewi,Pungki Yudy Andika Dewi. (2017). Pengaruh Pelatihan Cuci Tangan Pakai Sabun(CTPS) Terhadap Perilaku Mencuci Tangan Pada Anak Sekolah Dasar Di SDN Mangge2 Desa Mangge Kecamatan Barat Kabupaten Magetan Tahun 20017.

Kandari,Nahira.Horellafadjriah. (2020). Penyuluhan Physical 
Devi Rosita \& Nofa Krisdiana: Studi Deskriptif Perilaku Anak Usia 9-12 Tahun tentang Pencegahan Penularan COVID-19 di Madrasah Diniyah Awaliyah Ma'arif Nu 01 Al-Hidayah Demaan Jepara

Distancing Pada AnakAnak

Di PantiAsuhan Al Fakir;

Kusuma, Dianne amor. (2021). Penerapan Program

Darmasan Sadar Masker Pada Anak-Anak) Dalam Upaya Mengurangi Penyebaran Covid-19.

Nuraini,pradana AA dan casman (2020). Pengaruh kebijakan social distancing pada wabah COVID-19 terhadap kelompok rentan di Indonesia.Jurnal kebijakan kesehatan Indonesia.

Panggabean,FebeI manuelita Sitompul Monalisa. (2021). Perananan Orang Tua Terhadap Kepatuhan Cuci Tangan Pakai Sabun Pada Anak Usia Sekolah Selama Masa Pandemi.

Riyanto,Agus. (2011). Aplikasi Metode Penelitian Kesehatan. Yogyakarta: Nuha Medika.

Satgas penanganan covid19 kabupaten jepara. (2020). Sebaran kasus covid-19 di jepara.kabupaten

jepara.dinkes kabupaten jepara.

Satgas COVID-19.Tanya jawab satgas penanganan COVID 19.(di akses tanggal 23 september 2020).di dapat dari:

https://covid19.go.id/tanyajawab? page $=5$

Trianto. (2010). Pengantar Penelitian

Pendidikan

Bagi

Pengembangan Profesi

Pendidikan dan Tenaga

Kependidikan. Jakarta:

Kencana.

World Health Organization.Corona virus disease (COVID -19.di akses pada 23 september 2020).di dapat dari: https://www.who.imt/covid19

Zumadini,Alif Yanuar. Karyadi,bakti dan karisna. (2020) Edukasi Perilaku Hidup Bersih Dan Sehat (PHBS) Dalam Pencegahan Covid-19 Kepada Anak-Anak Di Panti Asuhan. 